\title{
MENGUAK PERSEPSI ETIKA MAHASISWA AKUNTANSI
}

\author{
Santi Novita \\ s_novita@yahoo.com \\ Fakultas Ekonomi dan Bisnis - Universitas Airlangga
}

\begin{abstract}
The aims of this study was to determine whether there were ethical perception differences among students based on academic major, gender, and religiosity. It explored whether there was a perception gap between accounting students and non-accounting students, between male and female students, and between religious and nonreligious students. The survey was conducted using questionnaire of 216 students to explore the ethical perception. It used five moral constructs: justice, relativism, egoism, utilitarianism, and deontology. At significant level of $5 \%$ with the independent sample $t$-tests, it was found that were different perception in justice, relativism, and deontology contracts between accounting and non-accounting students. It displayed that in most of construct accept deontological, the accounting students had higher ethical values compared to nonaccounting students. The second result displayed that female students showing higher ethical perception toward their male students, and finally it was not displayed that there was different ethical perception between religious and non-religious students.
\end{abstract}

Keywords: accounting, ethics, non-accounting, perception, students

\begin{abstract}
ABSTRAK
Tujuan dari penelitian ini adalah untuk menguji apakah ada perbedaan persepsi etika antara mahasiswa berdasarkan program studi, gender, dan religiusitas. Penelitian ini mencoba membandingkan apakah terdapat perbedaan persepsi etika antara mahasiswa akuntansi dan nonakuntansi, antara mahasiswa laki-laki dan perempuan, dan antara mahasiswa yang merasa dirinya religius dan non-religius. Survey dalam penelitian ini dilakukan dengan menggunakan kuesioner terhadap 216 mahasiswa menggunakan lima pilar etika yaitu: keadilan, relativisme, egoisme, utilitarianisme, dan deontologi. Pada level signifikansi $5 \%$ dengan menggunakan independent sample t-tests, hasil penelitian menyatakan bahwa ada perbedaan persepsi etika berdasar pilar keadilan, relativisme, dan deontologi antara mahasiswa akuntansi dan non-akuntansi yang menunjukkan bahwa di sebagian besar pilar selain deontologi, mahasiswa akuntansi memiliki persepsi etika yang lebih tinggi dibandingkan dengan mahasiswa non-akuntansi. Hasil kedua menunjukkan bahwa mahasiswa perempuan menunjukkan persepsi etika yang lebih tinggi daripada mahasiswa laki-laki. Uji berikutnya memberikan hasil bahwa tidak terdapat perbedaan persepsi antara mahasiswa yang menyatakan dirinya religius dan mahasiswa yang merasa non-religius.
\end{abstract}

Kata kunci: akuntansi, etika, mahasiswa, non-akuntansi, persepsi

\section{PENDAHULUAN}

Etika merupakan suatu topik yang masih menjadi bahan pembicaraan yang menarik, baik itu tentang konsep etika itu sendiri maupun pentingnya etika bagi suatu profesi maupun bisnis. Pertanyaan tentang etika suatu profesi seperti profesi akuntan banyak muncul seiring dengan munculnya skandal yang melibatkan orang-orang yang bergelut di bidang akuntansi. Hal ini cukup menorehkan sejarah panjang yang memprihatinkan bagi akuntan. Sebut saja skandal Waste Management tahun 1998, skandal Enron tahun 2001, dilanjutkan kasus World.Com dan Tyco tahun 2002, sampai dengan skandal Satyam tahun 2009. Semua skandal tersebut tentang keterlibatan peran akuntan mulai dari kasus menaikkan laba, 
memindahkan akun, atau menaikkan nilai aset.

Penelitian tentang etika ini dilakukan dengan berbagai macam topik dan tujuan mulai penelitian tentang penilaian Certified Public Accountant (CPA) terhadap kasus etika (Ward dan Alan, 1993), penelitian tentang pengaruh orientasi etika terhadap keputusan etika mahasiswa akuntansi (Radtke, 2004), dan penelitian di USA tentang bagaimana reaksi mahasiswa akuntansi melihat adanya berbagai skandal yang melibatkan profesi akuntan (Communale et al., 2006). Di Indonesia sendiri, penelitian tentang etika dilakukan dengan menguji perbedaan persepsi terhadap etika bisnis dan etika profesi jika dipandang dari segi gender dan disiplin akademis, memberikan hasil tidak terdapat perbedaan baik segi gender maupun disiplin akademis (Pratiwi, 2007). Penelitian lain tentang etika ini dilakukan untuk melihat etika dan peningkatan moral untuk mahasiswa aku tansi dan manajemen dengan membandingkan perkembangan sebelum dan sesudah mendapatkan mata kuliah etika (Najmudin dan Adawiyah, 2011).

Penelitian tentang etika yang dihubungkan dengan beberapa aspek di Barbados (Alleyne dan Persaud, 2012), dilakukan untuk menguji perbedaan persepsi mengenai etika berdasar gender, disiplin akademis, dan tingkat religiusitas. Dari uji gender memberikan hasil bahwa perempuan lebih menjunjung etika daripada lakilaki. Sementara salah satu hasil dari penelitian tersebut cukup mengejutkan bagi para akuntan yaitu mahasiswa non-akuntansi lebih menjunjung etika daripada mahasiswa akuntansi. Penelitian tersebut tentu memberikan hasil di luar harapan para akuntan. Hasil berikutnya adalah mahasiswa yang merasa tingkat religi tinggi lebih menjunjung etika daripada yang tingkat religi lebih rendah.

Berdasarkan penelitian sebelumnya, hasil yang diperoleh cukup beragam dari sudut pandang program studi antara akuntansi dan non-akuntansi. Demikian pula dari sisi gender masih menjadi per- debatan apakah perempuan lebih beretika daripada pria terutama terkait dengan posisi mereka di perusahaan dan bagai- mana mereka menghadapi kasus-kasus yang melibatkan etika (Sidani et al., 2009). Dari aspek religiusitas tentu tidak mengherankan bahwa hasil yang diperoleh adalah mahasiswa religius lebih menjunjung etika daripada mahasiswa non-religius, namun terdapat penelitian yang memberikan hasil sebaliknya. Sementara untuk dimensi religiusitas dimana persepsi akan tingkat religiusitas merupakan kombinasi dari aspek keyakinan (the ideological dimension) dan peribadatan (the ritualistic dimension), dimensi penghayatan (the experiental dimension), dimensi pengetahuan (intellectual dimension) dan dimensi pengamalan (consequential dimension) (Ismail, 2009), akan memberi sedikit warna apabila dilakukan di Indonesia karena bagi sebagian besar masyarakat di Indonesia menyatakan diri telah memenuhi kategori religius apabila telah ada dimensi keyakinan dan peribadatan.

Rumusan masalah dalam penelitian ini adalah (1) apakah terdapat perbedaan persepsi antara mahasiswa akuntansi dengan mahasiswa non-akuntansi tentang etika, (2) apakah terdapat perbedaan persepsi antara mahasiswa laki-laki dengan mahasiswa perempuan tentang etika, (3) apakah terdapat perbedaan persepsi antara mahasiswa religius dengan mahasiswa non-religius tentang etika.

Tujuan penelitian ini adalah untuk menguji perbedaan persepsi etika ditinjau dari program studi, gender, dan tingkat religiusitas. Adapun hasil dari penelitian ini diharapkan mampu untuk memberikan masukan pada program studi untuk evaluasi dan pengembangan kurikulum guna meningkatkan mutu pembelajaran dan pengembangan pendidikan akuntansi dimasa yang akan datang. Tujuan lain adalah sebagai bahan refleksi bagi mahasiswa akuntansi dan akuntan pada umumnya. Bagi user dari lulusan program studi ekonomi dan bisnis, agar dapat lebih mem- 
pertimbangkan faktor-faktor apa yang dapat dijadikan bahan dalam memilih calon karyawan.

\section{TINJAUAN TEORETIS \\ Etika dan Persepsi}

Etika diartikan sebagai ilmu tentang apa yang baik dan yang buruk terkait dengan hak dan kewajiban moral, kumpulan asas atau nilai yang berkenaan dengan moral, ataupun nilai mengenai apa yang benar dan tidak benar yang dianut suatu golongan masyarakat (Bertens, 2000: 25). Adapun persepsi merupakan proses bagaimana seseorang menyeleksi, mengatur, dan menginterpretasikan masukan-masukan informasi untuk menciptakan gambaran keseluruhan yang berarti (Kotler, 2000: 198). Pendapat lain menyatakan bahwa persepsi pada umumnya terjadi karena dua faktor yaitu faktor internal dan eksternal. Faktor internal berasal dari dalam diri individu, misalnya sikap, kebiasaan, dan kemauan. Faktor eksternal adalah faktor yang berasal dari luar individu, meliputi stimulus itu sendiri, baik sosial maupun fisik (Thoha, 2008: 147). Sementara ada beberapa faktor yang dapat memutarbalikkan persepsi yaitu pelaku persepsi, obyek yang dipersepsikan, dan konteks atau situasi dimana persepsi itu dilakukan. Individu akan berusaha mengembangkan penjelasan-penjelasan mengapa berperilaku dengan cara-cara tertentu (Robbins, 2003: 48).

Lima pilar konstruksi moral yang digunakan dalam melihat persepsi mengenai etika yaitu: (1) keadilan (justice), mengacu pada keseimbangan dan keadilan serta didasarkan pada keyakinan bahwa ada unsur keadilan untuk semua, layak, dan secara moral benar (Alleyne dan Persaud, 2012). (2) relativisme, hal ini mengacu pada aturan tertentu untuk kultur tertentu (Landry et al., 2004), dan disebutkan pula bahwa tindakan etis didasarkan apakah ditoleransi atau tidak oleh keluarga, budaya, atau tradisi (Alleyne dan Persaud, 2012). (3) egoisme, menganggap bahwa masing-masing individu mencoba untuk memaksimalkan kepentingan diri sendiri atau perilaku egois yang ditunjukkan dan dianggap oleh individu tersebut sebagai tindakan yang pantas atau benar (Landry et al., 2004). (4) utilitarianisme, mengacu pada kode etik yang memaksimalkan kepentingan dan mengurangi kerugian atau biaya (Landry et al., 2004), atau yang menyatakan bahwa utilitarianisme mengacu pada tindakan yang dapat diterima yang dapat memaksimalkan manfaat yang akan diperoleh (Karande et al., 2002). (5) deontologi, dapat diartikan sejauh mana tindakan seseorang konsisten dengan kewajiban individu maupun kewajiban tak tertulis (Cohen et al., 2001), atau mengacu pada eksistensi kewajiban yang tak tertulis yang mengikat individu terhadap lingkungan sosial atau masyarakat (Landry et al., 2004).

Bagaimana seseorang memiliki persepsi etika atau bagaimanakah seseorang memilih suatu keputusan tentang etika sangat dipengaruhi dari tahapan atau perkembangan berfikir seseorang (Kohlberg, 1976:31-53), yang melahirkan Cognitive Moral Development Theories (teori CMD) dimana perkembangan moral yang mempengaruhi pilihan akan suatu tindakan etis tersebut terdiri dari tiga tahap, yaitu preconventional level yang menyatakan bahwa pandangan ataupun tindakan masih dipengaruhi adanya aturan-aturan sosial dan adanya penghargaan ataupun adanya hukuman. Tahap konvensional, tahapan berfikir mulai terintervensi kelompok sosial apakah itu teman maupun lingkungan kerja dan terpengaruh dari ekspektasi orangorang disekitarnya. Tahap pasca conventional, pola berfikir dan bertindak sudah mulai mengarah pada prinsip diri yang tidak dipengaruhi oleh lingkungan sosial, sehingga pada tahap ini orang telah memiliki konsep diri yang tidak dipengaruhi oleh orang lain. Dikatakan pula bahwa kecepatan perkembangan tahapan ini adalah berbeda satu sama lain sehingga pada tahap mana seseorang berada tersebutlah yang mempengaruhi perbedaan pandangan maupun tindakan individu. 


\section{Penelitian Terdahulu dan Pengembangan Hipotesis}

Penelitian tentang etika pada perguruan tinggi khususnya untuk melihat tanggapan mahasiswa terhadap suatu isu etika bisnis dan juga sebagai bahan evaluasi bagi suatu perguruan tinggi akan kurikulum dan metode pembelajaran. Hal ini untuk mengetahui apakah mahasiswa memiliki pengetahuan akan etika dan dapat menerapkannya pada suatu kasus bisnis yang membutuhkan pemahaman akan etika. Penelitian tentang etika dalam pendidikan akuntansi dilakukan dan memberikan hasil bahwa ada perbedaan pandangan antara mahasiswa pada semester awal dan mahasiswa semester akhir yang telah menerima mata kuliah etika bisnis. Sementara itu, antara mahasiswa akuntansi dan bisnis tidak ada perbedaan pendapat terhadap keputusan yang diambil terkait dengan kasus yang diberikan. Perbedaan hanya pada sudut pandang sehingga memberikan alasan yang berbeda pula (Thomas, 2012).

Penelitian lain tentang persepsi mahasiswa akuntansi tentang etika yaitu penelitian tentang persepsi akuntan, mahasiswa akuntansi, dan karyawan bagian akuntansi dipandang dari segi gender terhadap etika bisnis dan etika profesi. Hasil penelitiannya adalah tidak terdapat perbedaan persepsi antara akuntan laki-laki dan perempuan serta mahasiswa akuntansi laki-laki dan perempuan. Hasil yang diperoleh adalah terdapat perbedaan persepsi antara karyawan bagian akuntansi laki-laki dan perempuan (Martadi dan Suranta, 2006).

Penelitian berikutnya menguji perbedaan persepsi terhadap etika bisnis dan etika profesi jika dipandang dari segi gender dan disiplin akademis (Pratiwi, 2007). Populasi penelitian ini adalah mahasiswa akuntansi, mahasiswa manajemen, mahasiswa administrasi, dan mahasiswa hukum serta dikelompokkan ke dalam kelompok mahasiswa non-akuntansi maupun non-manajemen. Hasil yang diperoleh tidak terdapat perbedaan persepsi mahasiswa terhadap etika bisnis maupun etika profesi jika dipandang dari segi gender dan disiplin akademis.

Penelitian tentang persepsi etika ini dilakukan pula di beberapa negara dengan tema yang berbeda seperti tentang pandangan mahasiswa akuntansi tentang persepsi akan kecurangan (Elias dan Faraq, 2010). Penelitian lain adalah persepsi mahasiswa akuntansi tentang etika yang dilakukan di sebuah kota kecil di Barbados (Alleyne dan Persaud, 2012), dengan melihat religiusitas, jenis kelamin, dan disiplin ilmu memberikan hasil bahwa perempuan menunjukkan nilai etika yang lebih tinggi daripada mahasiswa laki-laki, mahasiswa yang merasa tingkat religi tinggi lebih beretika dibandingkan mahasiswa yang merasa kurang tingkat religinya. Hasil berikutnya adalah mahasiswa non-akuntansi lebih menjunjung etika dibandingkan mahasiswa akuntansi.

\section{Hipotesis}

Berdasarkan teori CMD, lingkungan sosial, teman, dan lingkungan kerja dapat mempengaruhi perkembangan berfikir dan pilihan seseorang akan suatu keputusan. Hal ini dapat mendasari pilihan seseorang terhadap keputusan apakah sesuatu tersebut sesuai dengan etika ataupun sebaliknya bertentangan dengan etika. Beberapa penelitian terdahulu, perbedaan lingkungan, teman, dan beberapa faktor lain ini bisa dilihat dari sudut perbedaan gender, program studi, maupun religiusitas.

\section{Etika dan gender}

Penelitian di Indonesia tentang persepsi etika dilakukan dengan menguji perbedaan persepsi terhadap etika bisnis dan etika profesi jika dipandang dari segi gender dan disiplin akademis. Hasil penelitian ini menyatakan bahwa tidak terdapat perbedaan persepsi mahasiswa terhadap etika bisnis maupun etika profesi jika dipandang dari segi gender dan disiplin akademis (Pratiwi, 2007). 
Sementara penelitian lain memberikan hasil yang berbeda. Penelitian tersebut memberikan kesimpulan bahwa perempuan lebih beretika daripada laki-laki (Landry et al., 2004; Devonish et al., 2009; Sidani et al., 2009; Alleyne et al., 2010). Penelitian berikutnya yang memperkuat kesimpulan tersebut dilakukan terhadap mahasiswa akuntansi, memberikan hasil bahwa perempuan menunjukkan nilai etika yang lebih tinggi dari pada mahasiswa laki-laki (Alleyne dan Persaud, 2012). Berangkat dari penelitian dan teori ini dapat dinyatakan hipotesis sebagai berikut:

$\mathrm{H}_{1}$ : Ada perbedaan persepsi etika antara mahasiswa laki-laki dan perempuan.

\section{Akuntansi dan non-akuntansi}

Penelitian tentang adanya perbedaan persepsi antara mahasiswa akuntansi dan non-akuntansi tidak hanya sebatas persepsi tentang etika namun juga persepsi terhadap hal lain seperti terhadap suatu profesi misalnya CPA atau terhadap citra akuntansi. Penelitian ini memberikan hasil bahwa terdapat perbedaan persepsi antara mahasiswa akuntansi dan non-akuntansi tentang profesi CPA (Sugara dan Bolan, 2006). Penelitian berikutnya tentang persepsi antara mahasiswa akuntansi dan nonakuntansi juga memberikan hasil bahwa terdapat perbedaan persepsi antara kedua kelompok tersebut terhadap citra akuntansi (Allen, 2004).

Penelitian terhadap persepsi etika memberikan hasil bahwa terdapat perbedaan persepsi pada mahasiswa dengan disiplin ilmu yang berbeda. Mahasiswa akuntansi yang dianggap lebih sistematik dan kritis terhadap masalah etika, sementara mahasiswa non-akuntansi (bisnis/manajemen) lebih fokus terhadap bagaimana mengelola karyawan dan sumber daya dengan baik tentu memberi pandangan yang berbeda pula terhadap budaya maupun norma sosial (Landry et al., 2004).

Penelitian yang menguji perbedaan persepsi etika terhadap mahasiswa akun- tansi dan non-akuntansi (manajemen dan ekonomi) dilakukan pula di Barbados (Alleyne dan Persaud, 2012), dan memberikan hasil bahwa mahasiswa non-akuntansi lebih etis daripada mahasiswa akuntansi. Berdasarkan penelitian ini maka hipotesa kedua adalah sebagai berikut:

$\mathrm{H}_{2}$ : Ada perbedaan persepsi etika antara mahasiswa akuntansi dan non-akuntansi.

\section{Religiusitas}

Penelitian tentang tingkat religiusitas pada mahasiswa menunjukkan bahwa mahasiswa yang merasa lebih religius akan menunjukkan tingkat penghargaan yang tinggi pula terhadap norma yang diwujudkan dengan gaya hidup sehari-hari (Cagle dan Baucus, 2006). Penelitian tentang hubungan tingkat religiusitas mahasiswa dan perilaku maupun psikologis memberikan hasil senada bahwa ada hubungan positif antara faktor religi dengan psikologis yang baik (Garcia dan Valero, 2013). Tingkat religiusitas siswa akan diwujudkan dalam dimensi pengamalan (Ismail, 2009).

Penelitian lain memberikan hasil bahwa mahasiswa yang merasa dirinya memili$\mathrm{ki}$ nilai religiusitas yang baik memiliki persepsi etis yang lebih baik daripada mahasiswa yang tidak merasa religius (Alleyne dan Persaud, 2012), namun dalam penelitian ini apabila dibandingkan dari sudut gender, mahasiswa perempuan baik mereka yang merasa tingkat keimanannya tinggi maupun tidak, lebih menunjukkan tingkat etika yang lebih tinggi dari mahasiswa laki-laki. Berangkat dari hal tersebut maka hipotesa yang ketiga adalah:

$\mathrm{H}_{3}$ : Ada perbedaan persepsi antara mahasiswa religius dan non-religius tentang etika.

\section{Rerangka Konseptual Penelitian}

Berdasar gambaran hipotesa yang telah dikemukakan sebelumnya, maka disusun rerangka konseptual yang dapat di tunjukkan Gambar 1. 


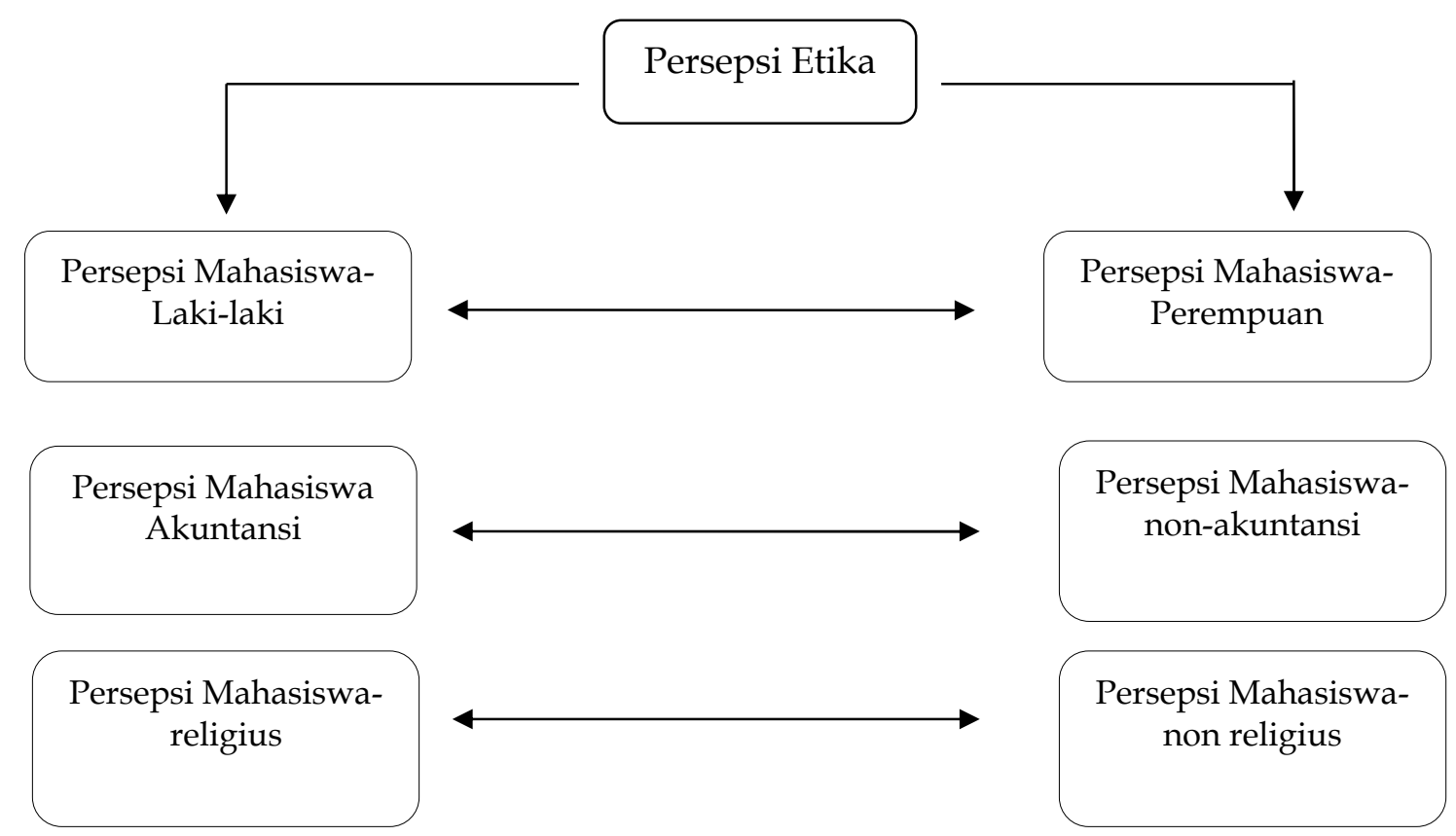

Sumber: Olahan Penulis

\section{Gambar 1 \\ Rerangka Konseptual Penelitian}

\section{METODE PENELITIAN Populasi dan sampel}

Populasi dalam penelitian ini adalah mahasiswa yang terdaftar pada program studi Akuntansi dan non-akuntansi (Manajemen dan Ekonomi Pembangunan) pada Fakultas Ekonomi dan Bisnis Universitas Airlangga. Sementara sampel penelitian diperoleh dengan cara menyebarkan kuesioner pada mahasiswa semester akhir dan diperoleh sampel penelitian sebanyak 216 kuesioner dengan rincian 120 mahasiswa akuntansi dan 96 mahasiswa non akuntansi, 116 mahasiswa perempuan dan 100 mahasiswa laki-laki, dan 185 mahasiswa yang mempersepsikan dirinya religius dan 31 mahasiswa non-religius. Dari jumlah tersebut untuk program studi Akuntansi sendiri terdiri dari mahasiswa 55 laki-laki dan 65 perempuan, sementara untuk mahasiswa yang mempersepsikan dirinya sebagai mahasiswa religius sebanyak 103 dan 17 orang mahasiswa non-religius.

\section{Jenis dan sumber data}

Jenis data yang digunakan dalam penelitian ini adalah data kuantitatif, semen tara sumber datanya adalah data primer yang dikumpulkan dengan cara melakukan penyebaran kuesioner. Pengumpulan data dengan cara mendistribusikan kuesioner di kelas terpilih yaitu pada mata kuliah tingkat akhir untuk mendapatkan sampel yang representatif. Kuesioner akan terbagi dua sesi yang terdiri dari data demografi yang meliputi jenis kelamin, umur, tingkat religius tinggi (ya atau tidak) dan disiplin ilmu. Sesi kedua dari kuesioner adalah beberapa pertanyaan tentang skenario etika untuk mengukur lima pilar moral sebagaimana digunakan oleh Landry et al. (2004). Dengan menggunakan skala likert, responden akan dimintai jawaban atas pertanyaan tentang dilema etika yang menggambarkan lima pilar dan karakteristiknya sebagai berikut: 
Tabel 1

Lima pilar Moral dan karakteristik

\begin{tabular}{|c|c|}
\hline Pilar & Kharakteristic \\
\hline \multirow[t]{3}{*}{ Keadilan } & Layak/pantas \\
\hline & Adil \\
\hline & Secara moral benar \\
\hline \multirow[t]{3}{*}{ Relativisme } & Diterima dari sudut pandang keluarga \\
\hline & Diterima dari sisi nilai budaya \\
\hline & Diterima dari sisi nilai tradisional \\
\hline \multirow[t]{2}{*}{ Egoisme } & Mempromosikan diri \\
\hline & Memuaskan diri \\
\hline \multirow[t]{2}{*}{ Utilitarianisme } & Menghasilkan manfaat yang besar \\
\hline & Memaksimalkan keuntungan dan mengurangi kerugian \\
\hline \multirow[t]{2}{*}{ Deontologikal } & Melanggar kontrak tidak tertulis \\
\hline & Melanggar janji tidak terucap \\
\hline
\end{tabular}

Sumber: Landry et al. (2004)

Responden akan diminta untuk memberikan point dari mulai point 1 sampai dengan 7 skala Likert untuk setiap kasus etika yang diberikan. Kasus terdiri dari delapan kasus sebagaimana digunakan dalam penelitian Landry et al. (2004), yang juga diadopsi oleh Alleyne dan Persaud (2012), pada Tabel 2. Tingkatan yang mereka berikan dalam setiap kasus akan menunjukkan apakah secara etika hal tersebut benar atau tidak. Adapun kasus yang diberikan adalah sebagai berikut:

Tabel 2

Skenario Etika

\begin{tabular}{cl}
\hline \hline Kasus & \multicolumn{1}{c}{ Skenario } \\
\hline 1 & Seorang manajer menyadari bahwa proyeksi penjualan triwulanan tidak akan \\
& terpenuhi dan dia tidak akan menerima bonus. Jika pesanan pelanggan dikirim \\
& lebih awal, maka akan ada kepastian bonus triwulanan tanpa ada pengaruh pada \\
penjualan tahunan. & \\
& Tindakan: Manajer mengirim pesanan pelanggan lebih awal pada kuartal ini untuk \\
& memastikan akan ada pendapatan bonus. \\
& Sebuah perusahaan baru yang menjanjikan, mengajukan pinjaman ke bank. Data \\
& historis kredit perusahaan tidak memenuhi kriteria pinjaman bank normal. \\
& Manajer kredit perbankan adalah teman dan mitra golf dari pemilik perusahaan. \\
& Tindakan: manajer kredit menyetujui pinjaman. \\
& Karena resesi, manajemen perusahaan menyadari perusahaan harus melakukan \\
& penghematan. Seorang karyawan lama dengan yang sering absen karena \\
& keluarganya ada yang sakit adalah yang paling mungkin untuk dihentikan. \\
& Tindakan: Manajer memberhentikan karyawan muda yang sangat kompeten yang \\
baru direkrut dan bukan karyawan lama tersebut. \\
Tanggung jawab pertama seorang manajer produk baru adalah untuk menjual \\
produk baru dan sukses yaitu peralatan dapur. Bonus gajinya didasarkan pada \\
penjualan produk. Dia menemukan bahwa produk tersebut tidak mendapatkan uji \\
produk yang memadai untuk memenuhi pedoman keamanan produk. Sejauh ini, \\
semua pengujian telah menunjukkan bahwa tidak ada masalah keamanan produk.
\end{tabular}




\begin{tabular}{cl}
\hline \hline Kasus & \multicolumn{1}{c}{ Skenario } \\
\hline 5 & Tindakan: Manajer menyetujui promosi dan penjualan produk. \\
& Seorang salesman yang memiliki dua anak yang masih kecil, dipromosikan untuk \\
pekerjaan yang menuntut banyak perjalanan dinas. Dia membebankan barang- \\
barang pribadi ke rekening pengeluaran perusahaan karena perjalanan tersebut \\
sering dan tidak nyaman untuk kehidupan keluarganya dan ini adalah praktek \\
yang biasa. \\
Tindakan: salesman membebankan \$ 50,00 untuk hadiah keluarga pada rekening \\
pengeluaran perusahaan. \\
Seorang CEO memberi instruksi kepada kontroler untuk mengurangi perkiraan \\
utang tak terpulihkan untuk meningkatkan pendapatan yang dilaporkan. CEO \\
berpendapat bahwa ini adalah praktek perusahaan yang lazim selama masa sulit. \\
Secara historis, perusahaan membuat penyisihan piutang yang sangat konservatif, \\
bahkan di tahun-tahun buruk. \\
Tindakan: Kontroler membuat penyesuaian untuk utang tak terpulihkan tersebut. \\
Seorang manajer perusahaan lokal ingin meningkatkan bisnis di luar negeri, telah \\
diminta untuk tidak mengungkapkan pembayaran kas ke distributor asing. \\
Pembayaran tersebut dicatat sebagai "goodwill gesture" untuk memungkinkan \\
perusahaan memperkenalkan produk di pasar luar negeri. Hal ini dianggap \\
praktek normal dan bukan sesuatu yang ilegal di negara asing. \\
Tindakan: Manajer lokal menyetujui pembayaran. \\
Seorang pemilik usaha kecil dalam bidang konsultasi kesulitan keuangan, \\
mendekati teman lama untuk menyalin database program perangkat lunak yang \\
akan meningkatkan penjualan di masa mendatang. Perangkat lunak tersebut \\
seharga \$500,00. \\
Tindakan: teman lama tersebut meminjamkan paket perangkat lunak
\end{tabular}

Sumber: Landry et al. (2004)

\section{Tehnik analisis}

Tehnik analisis ini bertujuan untuk menguji hipotesis apakah terdapat perbedaan persepsi etika antara mahasiswa akuntansi laki-laki dan perempuan, mahasiswa akuntansi dan non-akuntansi, antara non-religius dan religius. Uji yang digunakan independent $t$-test dengan menggunakan software SPSS 20. Uji Validitas Reliabilitas dilakukan terlebih dahulu sebelum melangkah pada analisa data. Uji reliabilitas ini dengan melihat Cronbach's Alpha >0,6 sehingga bisa dikatakan reliable untuk dilanjutkan pada uji selanjutnya.

\section{Uji Hipotesis}

Pengujian hipotesis yang digunakan adalah uji independent sample t-tests untuk menguji persepsi etika mahasiswa dari gender, disiplin ilmu, dan religiousity mahasiswa akan skenario etika yang diberikan.
Menggunakan $\mathrm{p}<0,05$ maka apabila nilai sig.(2-tailed) $<0,05$ maka dapat dijelaskan bahwa terjadi perbedaan persepsi etika antara kedua kelompok.

\section{Persepsi Etika Berdasar Gender}

Hipotesa pertama yaitu apakah ada perbedaan persepsi antara mahasiswa lakilaki dan perempuan terhadap etika maka dilakukan uji independent sample t-test dengan menggunakan kasus yang sama yaitu kasus 1 sampai dengan 8, serta menggunakan lima pilar moral dan signifikansi $\mathrm{p}<0,05$ dan diperoleh hasil sebagaimana tampak pada Tabel 3.

\section{Keadilan}

Pilar keadilan, hasil yang diperoleh adalah sig $<0,05$ untuk ketiga karakteristik sehingga dapat dikatakan bahwa terdapat perbedaan persepsi etika antara mahasiswa 
laki-laki dan perempuan. Apabila ditinjau dari rata-rata yang diperoleh dua kelompok tersebut misalkan karakteristik ketiga, nilai rata-rata mahasiswa perempuan $(\mathrm{M}=5,05)$ dan laki-laki $(\mathrm{M}=4,75)$. Hal ini menunjukkan persepsi mahasiswa perempuan terhadap tindakan manajer pada kasus yang diberikan tersebut secara moral lebih tidak benar dibandingkan dengan persepsi mahasiswa laki-laki. Demikian pula dengan karakter pertama dan kedua menunjukkan perempuan lebih tidak bisa mentoleransi tindakan manajer tersebut.

\section{Relativisme}

Untuk ketiga karakteristik pada pilar relativisme, maka terjadi perbedaan persepsi etika antara laki-laki dan perempuan $(\operatorname{sig}<0,05)$. Sementara apabila dilihat dari rata-rata maka laki-laki menganggap tindakan manajer lebih bisa diterima dari sisi budaya dan keluarga, sementara perempuan lebih tidak bisa menerima dari sisi pandang manapun. Hal ini sejalan dengan penelitian Landry et al. (2004), serta Alleyne dan Persaud (2012).

\section{Egoisme}

Hasil yang diperoleh tampak terjadi perbedaan persepsi antara mahasiswa lakilaki dan perempuan pada semua karakteristik (Sig. <0,05). Apabila ditinjau dari nilai rata-rata, maka mahasiswa laki-laki lebih menganggap bahwa tindakan manajer tersebut lebih egois daripada persepsi mahasiswa perempuan. Hal ini tidak sejalan dengan penelitian Alleyne dan Persaud (2012), dan Gismondi (2006), yang menyatakan perempuan lebih memandang bahwa hal tersebut menunjukkan keegoisan manajer.

\section{Utilitarianisme}

Berdasarkan hasil uji yang diperoleh, maka terjadi perbedaan persepsi antara mahasiswa laki-laki dan perempuan (sig < $0,05)$. Apabila dilihat dari nilai rata-rata mahasiswa, maka tampak bahwa mahasiswa perempuan menganggap bahwa yang dilakukan manajer akan lebih banyak kerugiannya daripada manfaatnya $(\mathrm{M}=4,16)$, dibanding pendapat mahasiswa laki-laki $(\mathrm{M}=3,88)$. Hal ini sejalan dengan penelitian Landry et al. (2004), maupun Alleyne dan Persaud (2012) dan mengindikasikan bahwa perempuan lebih percaya bahwa tindakan tersebut tidak membawa keuntungan bahkan dapat menimbulkan kerugian.

\section{Deontologikal}

Dengan $p<0,05$, maka perbedaan persepsi terjadi di karakteristik pertama dan kedua, yaitu dengan sig $<0,05$. Berdasarkan nilai rata-rata, maka mahasiswa laki-laki menganggap bahwa apa yang dilakukan manajer lebih melanggar kontrak tak tertulis di bandingkan persepsi mahasiswa perempuan. Hal ini tidak sejalan dengan penelitian Alleyne dan Persaud (2012), Adebayo (2005), dan Landry et al. (2004), namun sejalan dengan Borkowski dan Ugras (1992).

Tabel 3 tampak bahwa untuk keseluruhan pilar moral, maka terjadi perbedaan persepsi antara laki-laki dan perempuan. Dilihat dari pilar keadilan dan relativisme serta utilitarianisme, maka perempuan dianggap lebih tidak mentolelir tindakan manajer. Sensitifitas perempuan dari nilai-nilai keluarga, budaya, dan tradisional juga dinyatakan lebih tinggi daripada laki-laki. Hal ini sejalan Alleyne dan Persaud (2012), Gismondi (2006), dan Landry et al. (2004), yang dalam setiap pilar lebih banyak menyatakan bahwa perempuan memiliki posisi etika yang lebih tinggi dari laki-laki serta lebih berkomitmen pada nilai etika.

Dalam penelitian ini, tidak semua pilar perempuan bisa dikatakan lebih unggul dari segi etika daripada laki-laki sebagaimana dinyatakan dalam beberapa penelitian sebelumnya. Pilar egoisme dan deontologi tampak laki-laki lebih sensitif terhadap aturan yang tidak formal serta lebih menilai bahwa apa yang dilakukan manager tersebut adalah salah satu bentuk egoisme pribadi. Kajian lebih lanjut dalam program 
studi akuntansi, dari keseluruhan responden mahasiswa akuntansi yang berjumlah 120, apabila dibandingkan antara mahasiswa laki-laki dan perempuan yang tampak pada Tabel 4, menunjukkan bahwa untuk keseluruhan pilar moral mulai dari pilar keadilan sampai dengan deontologi tidak terjadi perbedaan persepsi tentang etika antara mahasiswa laki-laki dan perempuan, namun bila dilihat dari nilai rata-rata, pola yang ditunjukkan sama dengan uji untuk keseluruhan mahasiswa laki-laki dan perempuan dari keseluruhan program studi.

Tabel 3

Persepsi Etika Berdasar Gender

\begin{tabular}{|c|c|c|c|}
\hline Pilar & $\begin{array}{l}\text { Laki- } \\
\text { laki }\end{array}$ & $\begin{array}{c}\text { Perem- } \\
\text { puan }\end{array}$ & Sig \\
\hline \multicolumn{4}{|l|}{ Keadilan } \\
\hline 1 (pantas/layak) s/d 7 (tidak pantas) & 4,46 & 4,74 & 0,002 \\
\hline 1 (adil) s/d 7 (tidak adil) & 4,60 & 4,89 & 0,000 \\
\hline $\begin{array}{l}1 \text { (secara moral benar) s/d secara moral tidak benar } \\
\text { Relativisme }\end{array}$ & \multicolumn{3}{|c|}{ Relativisme } \\
\hline $\begin{array}{l}1 \text { (Diterima dari sisi keluarga) s/d } 7 \text { (Tidak Diterima dari sisi } \\
\text { keluarga) } \\
\text { (Diterima dari sisi budaya) s/d } 7 \text { (Tidak Diterima dari sisi }\end{array}$ & 3,95 & 4,21 & 0,001 \\
\hline budaya) & 4,08 & 4,47 & 0,001 \\
\hline $\begin{array}{l}1 \text { (Diterima dari aspek tradisional) s/d } 7 \text { (Tidak Diterima dari } \\
\text { aspek tradisional) } \\
\text { Egoisme }\end{array}$ & 4,19 & 4,48 & 0,000 \\
\hline 1 (Mempromosikan diri) s/d 7 (Tidak mempromosikan diri) & 3,88 & 4,13 & 0,003 \\
\hline $\begin{array}{l}1 \text { (Secara pribadi memuaskan) s/d } 7 \text { (Secara pribadi tidak } \\
\text { memuaskan) } \\
\text { Utilitarianisme }\end{array}$ & 3,95 & 4,18 & 0,009 \\
\hline $\begin{array}{l}1 \text { (Menghasilkan manfaat yang besar) } \\
\text { menghasilkan manfaat yang besar) }\end{array}$ & 3,96 & 4,16 & 0,019 \\
\hline $\begin{array}{l}1 \text { (Memaksimalkan keuntungan/meminimalisir kerugian) s/d } \\
7 \text { (Tidak memaksimalkan keuntungan/tidak meminimalisir }\end{array}$ & & & \\
\hline kerugian) & 3,88 & 4,16 & 0,002 \\
\hline \multicolumn{4}{|l|}{ Deontologikal } \\
\hline $\begin{array}{l}1 \text { (Melanggar kontrak tidak tertulis) s/d } 7 \text { (Tidak melanggar } \\
\text { kontrak tidak tertulis) }\end{array}$ & 3,85 & 4,08 & 0,007 \\
\hline $\begin{array}{l}1 \text { (Melanggar janji tidak terucap) s/d } 7 \text { (Tidak melanggar janji } \\
\text { tidak terucap) }\end{array}$ & 4,00 & 4,25 & 0,004 \\
\hline
\end{tabular}

Hasil yang diberikan dari kajian tentang beda persepsi antara laki-laki dan perempuan pada program studi Akuntansi ini berbeda dengan penelitian sebelumnya dimana hasil yang ditunjukkan adalah bahwa ada perbedaan antara laki-laki dan perempuan pada program studi Akuntansi dan menunjukkan bahwa mahasiswa perempuan lebih menunjukkan persepsi etika yang lebih tinggi daripada laki-laki (Alleyne dan Persaud, 2012). Sementara dalam penelitian ini tidak terjadi perbedaan persepsi dari sudut pandang gender dalam program studi Akuntansi. 
Tabel 4

Persepsi Etika Berdasar Gender-Mahasiswa Akuntansi

\begin{tabular}{|c|c|c|c|}
\hline Pilar & $\begin{array}{l}\text { Laki- } \\
\text { laki }\end{array}$ & $\begin{array}{l}\text { Perem } \\
\text {-puan }\end{array}$ & Sig \\
\hline \multicolumn{4}{|l|}{ Keadilan } \\
\hline 1 (pantas/layak) s/d 7 (tidak pantas) & 3,85 & 4,26 & 0,182 \\
\hline 1 (adil) s/d 7 (tidak adil) & 4,15 & 4,35 & 0,469 \\
\hline 1 (secara moral benar) s/d secara moral tidak benar & 4,38 & 4,63 & 0,381 \\
\hline \multicolumn{4}{|l|}{ Relativisme } \\
\hline 1 (Diterima dari sisi keluarga) s/d 7 (Tidak Diterima dari sisi & & & \\
\hline $\begin{array}{l}\text { keluarga) } \\
\text { (Diterima dari sisi budaya) s/d } 7 \text { (Tidak Diterima dari sisi }\end{array}$ & 3,70 & 3,89 & 0,557 \\
\hline budaya) & 4,05 & 4,36 & 0,270 \\
\hline $\begin{array}{l}1 \text { (Diterima dari aspek tradisional) s/d } 7 \text { (Tidak Diterima dari } \\
\text { aspek tradisional) }\end{array}$ & 4,24 & 4,23 & 0,983 \\
\hline \multicolumn{4}{|l|}{ Egoisme } \\
\hline 1 (Mempromosikan diri) s/d 7 (Tidak mempromosikan diri) & 3,67 & 4,00 & 0,265 \\
\hline $\begin{array}{l}1 \text { (Secara pribadi memuaskan) s/d } 7 \text { (Secara pribadi tidak } \\
\text { memuaskan) }\end{array}$ & 4,07 & 4,17 & 0,768 \\
\hline \multicolumn{4}{|l|}{ Utilitarianisme } \\
\hline $\begin{array}{l}1 \text { (Menghasilkan manfaat yang besar)s/d } 7 \text { tidak menghasilkan } \\
\text { manfaat yang besar) }\end{array}$ & 3,65 & 3,69 & 0,899 \\
\hline $\begin{array}{l}1 \text { (Memaksimalkan keuntungan/ meminimalisir kerugian) s/d } 7 \\
\text { (Tidak memaksimalkan keuntungan/tidak meminimalisir } \\
\text { kerugian) }\end{array}$ & 3,45 & 3,69 & 0,496 \\
\hline \multicolumn{4}{|l|}{ Deontologikal } \\
\hline $\begin{array}{l}1 \text { (Melanggar kontrak tidak tertulis) s/d } 7 \text { (Tidak melanggar } \\
\text { kontrak tidak tertulis) }\end{array}$ & 4,56 & 4,18 & 0,225 \\
\hline $\begin{array}{l}1 \text { (Melanggar janji tidak terucap) s/d } 7 \text { (Tidak melanggar janji } \\
\text { tidak terucap) }\end{array}$ & 4,67 & 4,35 & 0,322 \\
\hline
\end{tabular}

Sumber: Data Olahan

Hasil penelitian ini sejalan dengan Martadi dan Suranta (2006), yang meneliti tentang persepsi akuntan, mahasiswa akuntansi, dan karyawan bagian akuntansi dipandang dari segi gender terhadap etika bisnis dan etika profesi, dan hasil untuk pengujian mahasiswa akuntansi tidak terjadi perbedaan persepsi antara laki-laki dan perempuan. Penelitian lain yang mendukung yaitu Thomas (2012), dengan penelitiannya tentang pendidikan akuntansi menyatakan bahwa perbedaan persepsi akan kasus etika secara bertahap dapat diminimalisir dengan memberikan penekanan tertentu ketika mengajar mata kuliah etika. Hasil penelitian ini memungkinkan adanya kesamaan penekanan pada pilar atau aspek etika sehingga tidak adanya perbedaan antara laki-laki dan perempuan dalam satu program studi.

\section{Persepsi Etika dari Mahasiswa Akuntansi dan Non Akuntansi \\ Keadilan}

Uji apakah ada perbedaan persepsi etika antar mahasiswa akuntansi dan nonakuntansi untuk pilar keadilan maka digunakan uji independent sample t-test. Tabel 5 dapat diketahui bahwa baik mahasiswa akuntansi dan non-akuntansi rata-rata menyatakan bahwa tindakan manajer dari delapan kasus yang diberikan adalah tidak 
adil, tidak pantas dan tidak bermoral, namun hasil uji yang dilakukan memperlihatkan bahwa terdapat perbedaan persepsi terjadi pada pilar keadilan. Dengan $\mathrm{p}<$ 0,05, maka hasil yang diperoleh adalah Sig $<0,05$ di ketiga karakteristik. Berdasarkan rata-rata penilaian terhadap kasus tersebut, mahasiswa akuntansi menganggap tindakan manajer lebih tidak layak, tidak adil, dan lebih tidak bermoral dari mahasiswa non-akuntansi. Misal untuk karakteristik secara moral benar dan tidak nilai ratarata mahasiswa akuntansi $(\mathrm{M}=5,03) \mathrm{di}-$ banding mahasiswa non-akuntansi $(\mathrm{M}=$ 4,77). Hasil ini sejalan dengan penelitian Landry et al. (2004), namun tidak sejalan dengan penelitian Alleyne dan Persaud (2012).

\section{Relativisme}

Pilar relativisme terjadi perbedaan antara mahasiswa akuntansi dan non-akuntansi secara umum, namun apabila dilihat per kasus maka perbedaan persepsi antara mahasiswa akuntansi dan non-akuntansi tidak terjadi pada kasus 3 untuk karakteristik diterima dari sisi tradisional (traditionally acceptable). Hal ini berkebalikan dengan hasil penelitian dari Alleyne dan Persaud (2012), dimana pada penelitian tersebut terjadi perbedaan pada karakteristik traditionally acceptable. Rata-rata penilaian terhadap tindakan manajer maka di ketiga karakteristik tersebut mahasiswa akuntansi memberikan poin lebih tinggi daripada mahasiswa non-akuntansi sehingga tampak mahasiswa akuntansi lebih tidak dapat menerima tindakan manajer tersebut dari aspek manapun baik itu dari sisi keluarga, kultural maupun dari nilai tradisional. Sebagai contoh adalah pada aspek apakah tindakan manajer tersebut dapat diterima secara budaya, maka untuk mahasiswa akuntansi $(\mathrm{M}=4,39)$ sementara mahasiswa non-akuntansi $(M=4,16)$. Hal ini berbeda dengan penelitian Landry et al. (2004), dan Alleine dan Persaud (2012), dimana maha- siswa non-akuntansi lebih menyatakan tindakan tersebut tidak diterima dari sisi budaya.

\section{Egoisme}

Pilar ini tidak terjadi perbedaan persepsi antara mahasiswa akuntansi dan nonakuntansi dimana dengan $p<0,05$ hasil yang diperoleh sig $>0,05$. Apabila dilihat dari nilai rata-rata juga kedua kelompok tampak cenderung netral.

\section{Utilitarianisme}

Pilar utilitarisme, nilai sig $>0,05$ terjadi pada karakteristik pertama sehingga dapat dikatakan bahwa tidak terjadi perbedaan persepsi antara mahasiswa akuntansi dan non-akuntansi dari pandangan apakah tindakan manajer tersebut menghasilkan manfaat yang besar atau tidak. Karakteristik kedua terjadi perbedaan antara mahasiswa akuntansi dan non-akuntansi dengan nilai sig $<0,05$. Rata-rata yang ditunjukkan misal di karakteristik kedua yaitu memaksimalkan keuntungan dan meminimalkan kerugian dapat dilihat bahwa nilai rata-rata nilai mahasiswa akuntansi $(\mathrm{M}=4,12)$ dibandingkan dengan rata-rata non-akuntansi $(\mathrm{M}=$ 3,91 ) menggambarkan bahwa mahasiswa non-akuntansi lebih melihat hal tersebut tidak memaksimalkan keuntungan.

\section{Deontologikal}

Aspek ini, terjadi perbedaan rata-rata antara mahasiswa akuntansi dan nonakuntansi dengan $\mathrm{p}<0,05$ nilai sig $<0,05 \mathrm{di}$ kedua karakteristik. Adapun dari nilai ratarata seperti halnya karakteristik pertama yaitu apakah tindakan manajer melanggar kontrak tidak tertulis, maka nilai rata-rata mahasiswa akuntansi $(\mathrm{M}=4,26)$ lebih tinggi dibandingkan nilai rata-rata mahasiswa non akuntansi $(\mathrm{M}=3,61)$ dapat dikatakan mahasiswa non-akuntansi lebih memiliki persepsi yang kuat bahwa tindakan manajer tersebut melanggar aturan tidak tertulis. 
Tabel 5

Persepsi Mahasiswa: Akuntansi-Non Akuntansi

\begin{tabular}{|c|c|c|c|}
\hline Pilar & Acc & $\begin{array}{l}\text { Non- } \\
\text { Acc }\end{array}$ & Sig \\
\hline \multicolumn{4}{|l|}{ Keadilan } \\
\hline 1 (pantas/layak) s/d 7 (tidak pantas) & 4,84 & 4,33 & 0,000 \\
\hline 1 (adil) s/d 7 (tidak adil) & 4,92 & 4,55 & 0,000 \\
\hline 1 (secara moral benar) s/d 7 (secara moral tidak benar) & 5,03 & 4,77 & 0,031 \\
\hline \multicolumn{4}{|l|}{ Relativisme } \\
\hline \multicolumn{4}{|l|}{1 (Diterima dari sisi keluarga) s/d 7 (Tidak Diterima dari sisi } \\
\hline keluarga) & 4,17 & 3,98 & 0,020 \\
\hline (Diterima dari sisi budaya) s/d 7 (Tidak Diterima dari sisi budaya) & 4,39 & 4,16 & 0,004 \\
\hline $\begin{array}{l}1 \text { (Diterima dari aspek tradisional) s/d } 7 \text { (Tidak Diterima dari } \\
\text { aspek tradisional) }\end{array}$ & 4,40 & 4,28 & 0,138 \\
\hline \multicolumn{4}{|l|}{ Egoisme } \\
\hline 1 (Mempromosikan diri) s/d 7 (Tidak mempromosikan diri) & 4,01 & 4,01 & 0,985 \\
\hline $\begin{array}{l}1 \text { (Secara pribadi memuaskan) s/d } 7 \text { (Secara pribadi tidak } \\
\text { memuaskan) }\end{array}$ & 4,10 & 4,04 & 0,542 \\
\hline \multicolumn{4}{|l|}{ Utilitarianisme } \\
\hline $\begin{array}{l}1 \text { (Menghasilkan manfaat yang besar) s/d } 7 \text { (tidak menghasilkan } \\
\text { manfaat yang besar) }\end{array}$ & 4,12 & 4,01 & 0,194 \\
\hline $\begin{array}{l}\text { 1(Memaksimalkan keuntungan/meminimalisir kerugian) s/d } 7 \\
\text { (Tidak memaksimalkan keuntungan/tidak meminimalisir kerugi- } \\
\text { an) }\end{array}$ & 4,12 & 3,91 & 0,026 \\
\hline \multicolumn{4}{|l|}{ Deontologikal } \\
\hline $\begin{array}{l}1 \text { (Melanggar kontrak tidak tertulis) s/d } 7 \text { (Tidak melanggar } \\
\text { kontrak tidak tertulis) }\end{array}$ & 4,26 & 3,61 & 0,000 \\
\hline $\begin{array}{l}1 \text { (Melanggar janji tidak terucap) s/d } 7 \text { (Tidak melanggar janji } \\
\text { tidak terucap) }\end{array}$ & 4,43 & 3,76 & 0,000 \\
\hline
\end{tabular}

Sumber: Data Olahan

Berdasarkan pada dua kelompok yaitu akuntansi dan non-akuntansi secara keseluruhan, maka perbedaan persepsi etika terjadi pada pilar keadilan, relativisme, dan deontologikal. Aspek keadilan dimana terdapat tiga karakteristik tentang kelayakan, keadilan, dan moral, maka tampak mahasiswa akuntansi menganggap bahwa tindakan manajer pada kasus yang diberikan lebih tidak menunjukkan nilai keadilan. Hasil ini sejalan dengan Landry et al. (2004), yang menyatakan bahwa mahasiswa akuntansi lebih menyangkutpautkan kasus tersebut baik dengan kepatuhan pada prinsip akuntansi sebagaimana pengakuan pendapatan pada kasus 1, ataupun dengan prinsip lain yang berlaku umum. Sementara untuk pilar utilitarianime dan egoisme tidak terjadi perbedaan pada kedua kelompok dan hal ini sejalan dengan penelitian sebelumnya.

Pilar relativisme, tentang apakah tindakan tersebut dapat diterima dari sisi keluarga dan budaya maka terjadi pula perbedaan persepsi mahasiswa akuntansi dan nonakuntansi. Nilai rata-rata menunjukkan bahwa mahasiswa akuntansi memiliki tendensi yang lebih tinggi dalam menilai apakah tindakan tersebut dapat diterima dari nilai-nilai yang ditanamkan keluarga maupun budaya.

Pilar deontologikal, terjadi perbedaan persepsi dimana mahasiswa non-akuntansi lebih memiliki persepsi yang kuat bahwa 
tindakan manajer tersebut melanggar aturan tidak tertulis dan janji tak terucap. Hal ini sejalan dengan penelitian Alleyne dan Persaud (2012), dan Landry et al. (2004), yang menyatakan bahwa mahasiswa nonakuntansi mungkin tidak terlalu berpegang pada aturan legal atau prinsip-prinsip tertentu, namun lebih sadar akan konsekuensi lain yang lebih besar bagi perusahaan.

Perbedaan tentang bagaimana mahasiswa akuntansi dan bisnis dalam menyikapi suatu kasus etika bisnis ini dari berbagai pilar apakah itu deontologikal, relativisme, ataupun pilar yang lain menjadi bahan dalam penelitian Thomas (2012), tentang pendidikan akuntansi, dimana perbedaan tersebut secara bertahap dapat diminimalisir dengan memberikan penekanan yang berbeda ketika mengajar mata kuliah etika pada dua kelompok mahasiswa ini. Penekanan tersebut didasarkan pada pilar yang manakah dari masing-masing group tersebut kurang dipertimbangkan dalam menilai suatu kasus etika yang dihadapi.

\section{Religiusitas}

Uji terhadap hipotesa ketiga yaitu apakah ada perbedaan persepsi antara mahasiswa yang merasa religius dan non-religius terhadap etika maka dilakukan uji independent sample t-test dengan menggunakan kasus yang sama yaitu kasus 1 sampai dengan 8, serta menggunakan lima pilar moral dan signifikansi $\mathrm{p}<0,05$ maka diperoleh hasil pada Table 6 sebagai berikut:

\section{Keadilan}

Dengan $\mathrm{p}<0.05$ dan hasil yang diperoleh sig>0.05 maka dapat dikatakan bahwa pada ketiga karakteristik pilar keadilan tidak terdapat perbedaan persepsi antara mahasiswa religius dan non-religius.

\section{Relativisme}

Karakteristik pada pilar relativisme, maka tidak terjadi perbedaan persepsi antara mahasiswa religious dan non-religius (sig $>0,05)$ pada ketiga karakteristik.

\section{Egoisme}

Hasil yang diperoleh tampak tidak terjadi perbedaan persepsi antara mahasiswa religius dan non-religius pada karakteristik pertama $(\operatorname{Sig}>0,05)$. Karakteristik kedua terjadi perbedaan persepsi antara mahasiswa religius dan non-religius dimana nilai sig. $<0,05$. Apabila dilihat dari nilai rata-rata yang diperoleh maka mahasiswa yang mempersepsikan dirinya religius lebih menganggap bahwa tindakan manager tersebut lebih cenderung egois.

\section{Utilitarianisme}

Hasil yang diperoleh maka tidak terdapat perbedaan persepsi antara mahasiswa religius dan non-religius $($ sig $>0,05)$ pada karakteristik pertama. Karakteristik kedua terjadi perbedaan persepsi etika. Apabila dilihat dari nilai rata-rata mahasiswa maka tampak bahwa mahasiswa non-religius menganggap bahwa yang dilakukan manajer akan lebih banyak kerugiannya daripada manfaatnya $(M=4,29)$, dibanding pendapat mahasiswa religius $(M=3,98)$. Hal ini tidak sejalan dengan penelitian Alleyne dan Persaud (2012).

\section{Deontologikal}

Dengan $p<0,05$, maka tidak ada perbedaan persepsi di semua karakteristik, dimana hasil yang diperoleh adalah sig $>0,05$. Hal ini tentu tidak sejalan dengan penelitian Alleyne dan Persaud (2012), maupun Singhapakdi et al. (1999), dan Barnett et al. (1996).

Berdasarkan keseluruhan pilar moral, perbedaan antara mahasiswa yang menyatakan dirinya religius dan non-religius secara umum tidak terjadi perbedaan persepsi diantara kedua kelompok tersebut.

Perbedaan terjadi hanya di sebagian karakteristik yaitu pada pilar egoisme dan utilitarianisme. Hal ini tidak sejalan dengan penelitian Alleyne dan Persaud (2012), Singhapakdi et al. 
Tabel 6

Persepsi mahasiswa-Religiusitas

\begin{tabular}{|c|c|c|c|}
\hline & Religius & $\begin{array}{c}\text { Non- } \\
\text { religius }\end{array}$ & Sig \\
\hline \multicolumn{4}{|l|}{ Keadilan } \\
\hline 1 (pantas/layak) s/d 7 (tidak pantas) & 4,58 & 4,81 & 0,063 \\
\hline 1 (adil) s/d 7 (tidak adil) & 4,74 & 4,88 & 0,231 \\
\hline 1 (secara moral benar) s/d secara moral tidak benar & 4,89 & 5,08 & 0,264 \\
\hline \multicolumn{3}{|l|}{ 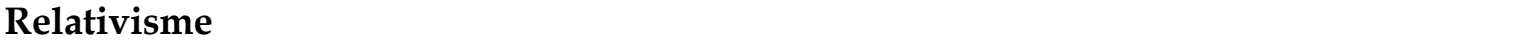 } & \\
\hline $\begin{array}{l}\text { keluarga) } \\
\text { (Diterima dari sisi budaya) s/d } 7 \text { (Tidak Diterima dari sisi }\end{array}$ & 4,07 & 4,22 & 0,199 \\
\hline budaya) & 4,27 & 4,40 & 0,259 \\
\hline $\begin{array}{l}1 \text { (Diterima dari aspek tradisional) s/d } 7 \text { (Tidak Diterima dari } \\
\text { aspek tradisional) }\end{array}$ & 4,33 & 4,47 & 0,213 \\
\hline \multicolumn{4}{|l|}{ Egoisme } \\
\hline 1 (Mempromosikan diri) s/d 7 (Tidak mempromosikan diri) & 4,00 & 4,08 & 0,506 \\
\hline $\begin{array}{l}1 \text { (Secara pribadi memuaskan) s/d } 7 \text { (Secara pribadi tidak } \\
\text { memuaskan) }\end{array}$ & 4,04 & 4,28 & 0,046 \\
\hline \multicolumn{4}{|l|}{ Utilitarianisme } \\
\hline menghasilkan manfaat yang besar) & 4,04 & 4,25 & 0,081 \\
\hline $\begin{array}{l}\text { 1(Memaksimalkan keuntungan/meminimalisir kerugian) s/d } 7 \\
\text { (Tidak memaksimalkan keuntungan/tidak meminimalisir } \\
\text { kerugian) }\end{array}$ & 3,98 & 4,29 & 0,015 \\
\hline \multicolumn{4}{|l|}{ Deontologikal } \\
\hline $\begin{array}{l}1 \text { (Melanggar kontrak tidak tertulis) s/d } 7 \text { (Tidak melanggar } \\
\text { kontrak tidak tertulis) }\end{array}$ & 4,00 & 3,83 & 0,175 \\
\hline $\begin{array}{l}1 \text { (Melanggar janji tidak terucap) s/d } 7 \text { (Tidak melanggar janji } \\
\text { tidak terucap) }\end{array}$ & 4,15 & 4,05 & 0,435 \\
\hline
\end{tabular}

Sumber: Data Olahan

(1999), Barnett et al. (1996), yang menyatakan bahwa mahasiswa religius lebih memperhatikan nilai etika pada keseluruhan kasus yang diberikan, namun apabila dicermati kembali penelitian sebelumnya, hal ini juga bukan sesuatu yang mengherankan. Hasil penelitian Alleyne dan Persaud (2012), ketika menguji mahasiswa laki-laki religius dan membandingkannya dengan mahasiswa perempuan yang nonreligius hasilnya ternyata menunjukkan bahwa mahasiswa laki-laki religius memiliki persepsi etika yang lebih tinggi hanya pada dua karakteristik, sementara 10 karakteristik lainnya menunjukkan bahwa perempuan non-religius menunjukkan persepsi etika yang lebih baik.

\section{SIMPULAN DAN SARAN \\ Simpulan}

Berdasarkan hipotesis pertama yaitu apakah ada perbedaan persepsi etika antara mahasiswa akuntansi dan non-akuntansi, maka diperoleh hasil bahwa terdapat perbedaan persepsi antara mahasiswa tersebut dari pilar keadilan, relativisme, dan deontologikal. Sementara tidak terdapat perbedaan persepsi dari pilar egoisme dan utilitarianisme. Nilai rata-rata yang ditunjukkan, maka dapat dikatakan pada sebagian besar pilar maka mahasiswa 
akuntansi menunjukkan nilai etika yang lebih tinggi, sementara mahasiswa nonakuntansi rata-rata nilai etika lebih tinggi pada pilar deontologikal.

Uji hipotesa yang kedua tentang apakah ada perbedaan persepsi antara laki-laki dan perempuan, maka hasil menunjukkan terdapat perbedaan di semua pilar moral yaitu keadilan, relativisme, egoisme, utilitarianisme, dan deontologikal. Apabila dilihat dari nilai rata-rata yang dihasilkan, secara umum perempuan dapat dianggap lebih beretika. Hal ini dapat ditunjukkan dari nilai rata rata pilar keadilan, relativisme, dan utilitarianisme. Sementara laki-laki lebih peka terhadap etika pada pilar egoisme dan deontologikal. Mahasiswa laki-laki dan perempuan pada program studi Akuntansi tidak terjadi perbedaan persepsi di kelima pilar moral tentang etika.

Uji hipotesis pada aspek religiusitas yaitu antara mahasiswa yang mempersepsikan diri sebagai mahasiswa religius dan non-religius memberikan hasil bahwa secara umum tidak terdapat perbedaan persepsi antara kedua kelompok tersebut tentang etika.

\section{Saran}

Populasi dan sampel pada penelitian ini terfokus pada satu universitas saja sehingga hasil penelitian tidak dapat di generalisasi. Penelitian selanjutnya lebih baik digunakan sampel yang lebih banyak dan meliputi beberapa universitas. Riset ini tidak memberikan kesempatan bagi responden untuk mendiskusikan pandangan atau pendapat akan solusi dari kasus yang diberikan tersebut sehingga untuk penelitian selanjutnya hal ini bisa digabungkan dengan riset kualitatif dengan interview maupun focus group discussion yang akan lebih menggali pandangan akan etika.

Religiusitas dalam penelitian dimaknai oleh responden sebagai kombinasi dari aspek keyakinan (ideological) dan peribadatan (ritualistic), belum menyentuh aspek yang lebih mendalam tentang kualitas dari kedua hal tersebut, sehingga penelitian selanjutnya dapat lebih dikembangkan dengan mempertimbangkan kualitas dan aspek yang berikutnya seperti aspek penghayatan (the experiential dimension).

\section{DAFTAR PUSTAKA}

Adebayo, O. B. 2005. Gender and Attitude Toward Professional Ethic: A Nigeria Police Perspective. African Security Review 14(2): 93-100.

Allen, C. L. 2004. Business Students' Perception of the Image of Accounting. Managerial Auditing Journal 19(2): 235-25.

Alleyne, P. dan N. Persaud. 2012. Exploring Undergraduate Students' Ethical Perceptions in Barbados, Differences by Gender, Academic Major and Religiosity. Journal of International Education in Business 5(1): 5-21.

Barnett, T., K. Bass, G. Brown. 1996. Religiusity, Ethical Ideology and Intentions to Report a Peer's Wrongdoing. Journal of Business Ethics 15: 1161-74.

Bertens, K. 2000. Etika. Gramedia Pustaka Utama. Jakarta.

Borkowski, S. C. dan Y. J. Ugras. 1992. The Ethical Judgement of College Students Regarding Business Issue. Journal of Education for Business 69(6): 333-338.

Cagle, J. dan M. Baucus. 2006. Case Studies of Ethics Scandals: Effects on Ethical Perceptions of Finance Students. Journal of Business Ethics 64(3): 213-29.

Cohen, J. R., L. W. Pant, D. J. Sharp. 2001. An Examination of Differences in Ethical sDecision-Making between Canadian Business Student and Business Profesional. Journal of Business Ethic 30: 319-336.

Communale, C. L., T. R. Sexton, S. C. Gara. 2006. Professional Ethical Crises: A Case Study of Accounting Majors. Managerial Auditing Journal 21: 636-56.

Devonish, D., P. Alleyne, C. CadoganMcClean, D. Greenidge. 2009. An Empirical Study of Future Professionals' Intentions to Engage in Unethical Business Practices. Journal of Academic Ethics 7(3): 159-73. 
Elias, R. Z. dan M. Faraq. 2010. The Relationship Between Accounting Students' Love of Money and Their Ethical Perception. Managerial Auditing Journal 25(3): 269-281

Garcia, J. dan A. G. B. Valero. 2013. Religious Orientation and Psichological Well-Being Among Spanish Undergraduate. Accion Psicologica 10(1): 133148.

Gismondi, A. 2006. The Downside of The Internet: Cheating and Technology in Higher Education. Journal of College and Character 7(5): 1-4.

Ismail, W. 2009. Analisis Komparatif Perbedaan Tingkat Religiusitas Siswa di Lembaga Pendidikan Pesantren, MAN, dan SMUN. Lentera Pendidikan 12(1): 87102.

Karande, K., C. Rao, A. Singhapakdi. 2002. Moral Philosophies of Marketing Managers: A Comparison of American, Australian and Malaysian Cultures. European Journal of Marketing 36(7/8): 768-91.

Kohlberg, L. 1976. Moral Stages and Moralization: The Cognitive-Developmental Approach. In Moral Development and Behavior: Theory, Research, and Social Issues. Holt, Rinehart \& Winston. New York.

Kotler, P. 2000. Marketing Management: Analysis, Planning, Implementation, and Control. 9th ed. Prentice Hall International. New Jersey.

Landry, R., D. G. Moyes, C. A. Cortes. 2004. Ethical Perceptions Among Hispanic Students: Differences by Major and Gender. Journal of Education for Business 80(2): 102-8.

Martadi, I. F. dan S. Suranta. 2006. Persepsi Akuntan, Mahasiswa Akuntansi, dan Karyawan Bagian Akuntansi Dipandang dari Segi Gender Terhadap Etika Bisnis dan Etika Profesi: Studi di Wilayah Surakarta. Prosiding Simposium Nasional Akuntansi IX. IAI-KAPd Agustus.
Najmudin dan W. R. Adawiyah. 2011. Studi tentang Intervensi Etika dan Peningkatan Moral Mahasiswa. Jurnal Bisnis dan Ekonomi 18(1): 69-83.

Pratiwi, N. 2007. Persepsi Mahasiswa Terhadap Etika Bisnis dan Etika Profesi Dipandang dari Segi Gender dan Disiplin Akademis. Thesis. Universitas Muhammadiyah Surakarta.

Radtke, R. R. 2004. Exposing Accounting Students to Multiple Factors Affecting Ethical Decision Making. Issues in Accounting Education 19(1): 73-84.

Robbins, S. P. 2003. Perilaku Organisasi. Jilid 1. PT Index kelompok Gramedia. Jakarta.

Sidani, Y., I. Zbib, M. Rawwas, T. Moussawer. 2009. Gender, Age, and Ethical Sensitivity: The Case of Lebanese Workers. Gender in Management: An International Journal 24(3): 211-27.

Singhapakdi, A., S. Vitell, G. Franke. 1999. Anticedents, Consequences, and Media ting Effects of Perceived Moral Intensity and Personal Moral Philosophies. Journal of the Academy of Marketing Science 27(1): 19-36.

Sugara, S. dan G. Boland. 2006. Perceptions of The Certified Public Accountants by Accounting and Non-Accounting Tertiary Students in Japan. Asian Review of Accounting 14(1/2): 149-167.

Thoha, M. 2008. Perilaku Organisasi: Konsep dan Aplikasinya. Rajawali Press. Jakarta.

Thomas, S. 2012. Ethics and Accounting Education. Issues in Accounting Education 27(2): 399-418.

Ward, S. P., D. R. Ward, B. D. Alan. 1993. Certified Public Accountant: Ethical Perception Skills and Attitudes on Ethics Education. Jurnal of Business Ethic 12: 601-610. 